\title{
Statistical Analysis in Fluvial Sediments of Selangor Rivers: Downstream Variation in Grain Size Distribution
}

\author{
Analisis Statistik Sedimen Fluvial Sungai-sungai di Selangor: Perubahan Agihan Partikel Saiz di Hiliran
}

Siti Aminah Bassa Nawang, Mohd Noor Shafique Rahman \& Wan Hanna Melini Wan Mohtar*

ABSTRACT

Statistical analysis and downstream variation in the fluvial sediment mixture were studied along three different rivers in Selangor i.e. Sungai Langat (Sg. Langat), Sungai Selangor (Sg. Selangor) and Sungai Tengi (Sg. Tengi). The aim of this study is to analyse the changes in grain size distribution in the downstream direction in three different classes of rivers, less, medium and fully development along the river banks. Samples were spatially and systematically collected at a distance about 3-5 kilometers between each point. Sediments were dried, sieved and further characterised using the GRADISTAT software. Results showed that the mean size of bed materials in Sg. Selangor and Sg. Langat were decreasing along the downstream towards the estuary. Meanwhile, an opposite trend was obtained for Sg. Tengi where the mean size of the bed material was found increasing towards the downstream of Sg Tengi's river mouth. Different variation was also observed for sediment parameters of sorting and skewness which reflect decreasing of sediment size follow the downstream of the rivers. Furthermore statistical analysis of kurtosis showed that there were no variation occurs along the three rivers where most of the sediment mixture is a mesokurtic type, normal distribution of bed sediment sizes. Beside that statistical analysis also show from the bivariate plots indicate that the sediments are mostly medium sand, poorly sorted and has profile of either symmetrical or fine skewed.

Keywords: Grain size distribution; Sungai Langat; Sungai Selangor; Sungai Tengi

ABSTRAK

Analisis statistikal dan perubahan hilir bagi campuran sedimen fluvial dikaji bagi tiga sungai berbeza di Selangor iaitu Sg. Langat, Sg. Selangor dan Sg. Tengi. Tujuan kajian ini adalah untuk menganalisa perubahan agihan saiz partikel mengikut arah hiliran bagi kelas sungai yang berbeza mengikut aras pembangunan di tebing iaitu kurang, sederhana dan sepenuhnya. Sampel diambil mengambil kira ruang dan bersistematik di mana setiap titik persampelan mempunyai jarak di antara 3-5 kilometer. Sedimen dikeringkan, disaring dan seterusnya dicirikan dengan menggunakan perisian GRADISTAT. Keputusan menunjukkan saiz bagi campuran sedimen dasar di Sg. Selangor dan Sg. Langat menurun mengikut arah hulu ke hiliran muara sungai. Sementara itu profil terbalik diperolehi bagi sedimen di Sg. Tengi di mana didapati saiz purata sedimen dasar meningkat menuju hiliran Sg. Tengi. Perubahan yang berbeza turut dilihat bagi parameter statistik pengisihan dan kepencongan dengan penurunan pada arah hiliran sungai. Tambahan pula analisa statistik kurtosis menunjukkan tiada perubahan bagi ketiga-tiga sungai dan kebanyakan campuran sedimen bersifat mesokurtik, saiz sedimen dasar bertaburan secara normal. Selain itu, analisa statistik plot dwivariat pula menunjukkan bahawa sedimen fluvial di kawasan kajian adalah kebanyakkannya bersifat pasir sederhana, pengisihan lemah dan mempunyai profil kepencongan sama ada simetri atau kepencongan halus.

Kata kunci: agihan saiz partikel; Sungai Langat; Sungai Selangor; Sungai Tengi

\section{INTRODUCTION}

The grain size distribution is parts of the important fundamental physical attributes of soil and it influences on the properties of soil, such as soil erosion, water movement and productivity (Dongwei et al. 2010). Essential factor of regulating channel morphology and hydraulics is bed material size and its rate affects the sediment transportation and the downstream changes (Reid et al. 1997). Previous study shows that downstream fining factor in fluvial systems was due to selective sorting (Ferguson et al. 1996).
Gasparini et al. (1999) stated that river tributaries can disturb the fining patterns in the fluvial system. In their theory, the combination of selective transport with a model of river-basin showed that downstream fining can be produced either with the factors of selective deposition or abrasion.

In 1999, Rice proved that Sukunka River downstream fining was not affected by abrasion process and strongly agreed by Ferguson et al. (1996) that sorting was the factor in downstream fining along Allt Dubhaig and Paola et al. (1992) then agreed that selective depositions was the natural factors for downstream fining. Different explanation of 
downstream fining in Waipaoa River, proved that concave configuration down along the river profile was controlling the hydraulics outflow transition in response of downstream fining (Gomez et al. 2001). Both fine and coarse size fractions can cause fining in large percentiles and both gravel and sand bed rivers can occur in the fining process (Gomez et al. 2001; Frings 2007). Method of granulometric shows the relation of ancient sediments with recent sediments in their textural properties concentrated from modern sedimentary environments (Amireh 2015).

Previous studies showed that only limited studies examined the distribution in large sand-bed rivers. Frings (2007) reviewed the factor affects the process in downstream fining of the gravel bed river with three categories which were abrasion, selective transport and sediment additionextraction. Persistent lithologies, small grain size, high degree of rounding, influence of grinding as abrasion process and the dominant in suspended transport mode are the factors of small abrasion rates in large sand-bed rivers. The upstream part of the rivers shows the higher abrasion rate nevertheless. Sometimes the coarse particles show mobility higher than the fine grains in the downstream side with few indicators, differ with abrasion, river with concave profile causes the selective transport produce a 'stable' downstream fining pattern. A stronger downstream fining rate may sometime be decreased due to the overbank sedimentation in large sand bed rivers and the removal of fine grains from the rivers. Other anthropogenic factors related including dredging effect depends on the volume and the grain size involved. Alternatively, coarse grain loss may occur due to the meander migration from the channel in aggrading circumstances, increasing the rate of downstream fining (Frings 2007).

The aims of this study are to (a) analyses the grain size changes in the downstream direction of selected rives in Selangor districts (b) differentiate the downstream fining variation among three rivers (c) recognize and explain the downstream changes among the selected three rivers.

\section{SAMPLING METHODS}

Bed samples were collected from three main rivers in the state of Selangor, south west of Peninsular Malaysia, i.e Sungai Tengi (Sg. Tengi), Sungai Selangor (Sg. Selangor) and Sungai Langat (Sg. Langat). Table 1 shows the details of the river and its catchment area which include seven rivers with total length of $753 \mathrm{~km}$.

TABLE 1. Selangor Rivers and catchment area inventory

\begin{tabular}{clcl}
\hline No. & River Catchment & Length $(\mathrm{km})$ & \multicolumn{1}{c}{ District involved } \\
\hline 1 & Sg. Bernam & 216 & Sabak Bernam, Upstream Selangor \\
2 & Sg. Tengi & 58 & Kuala Selangor, Sabak Bernam, Upstream Selangor \\
3 & Sg. Selangor & 134 & Kuala Selangor, Upstream Selangor, Gombak \\
4 & Sg. Buloh & 49 & Kuala Selangor, Gombak, Petaling \\
5 & Sg. Klang & 98 & Klang, Petaling, Kuala Langat, Sepang, Gombak \\
6 & Sg. Langat & 180 & Kuala Langat, Sepang, Gombak \\
7 & Sg. Sepang & 18 & Sepang \\
& Total Length: & 753 & \\
\hline
\end{tabular}

Sampling area for Sg. Tengi, Sg. Selangor and Sg. Langat are shown in Figure 2 a, b and c, respectively. These rivers were chosen to suit our initial river classification according to the development on the river bank. Three classes were identified as less, medium and fully developed, where Sg Tengi, Sg. Selangor and Sg. Langat fit the description, respectively. These rivers are accessible and cover most of the districts in Selangor including districts of Kuala Selangor, Sabak Bernam, Hulu Selangor, Gombak, Kuala Langat and Sepang.

Series of fieldwork were arranged for sampling collection with the samples were spatially distance in the range of $5 \mathrm{~km}$ apart from one to the other which then recorded accurately using a standard GPS. The sampling were designed as such to investigate the longitudinal, vertical and temporal variations in the bed materials (Surian 2002). Samples from Sungai Tengi and Sungai Selangor were collected by boat, and a low cost, self-made vacuum tube (Figure 1) was designed specially to collect sample in Sungai Langat due to inaccessibility to the river.

Bed samples were taken at the middle of each river (that is the most active region) using a grab sampler and were immediately sealed in an airtight container. A total of 27 samples were collected from these three rivers. There are nine samples for Sg. Tengi, 10 samples for Sg. Langat and eight samples for Sg. Selangor. Samples were dried in the oven at $105^{\circ} \mathrm{C}$ for 12 hours prior physical sieving using sieve series, including 4.75, 2.36, 1.18, 0.6, 0.3, 0.15 and $0.075 \mathrm{~mm}$ in sizes. Sieve analysis is a common procedure used to assess the particle size distribution of a granular material including sand (Sonaye and Baxi 2012).

Statistical analysis was conducted for each collected sample using the formulae developed by Folk \& Ward (1975), described in detail Table 2. The main focus in the analysis is to measure the central tendency (mean), degree of scatter (sorting), skewness and degree of peak through kurtosis. The 


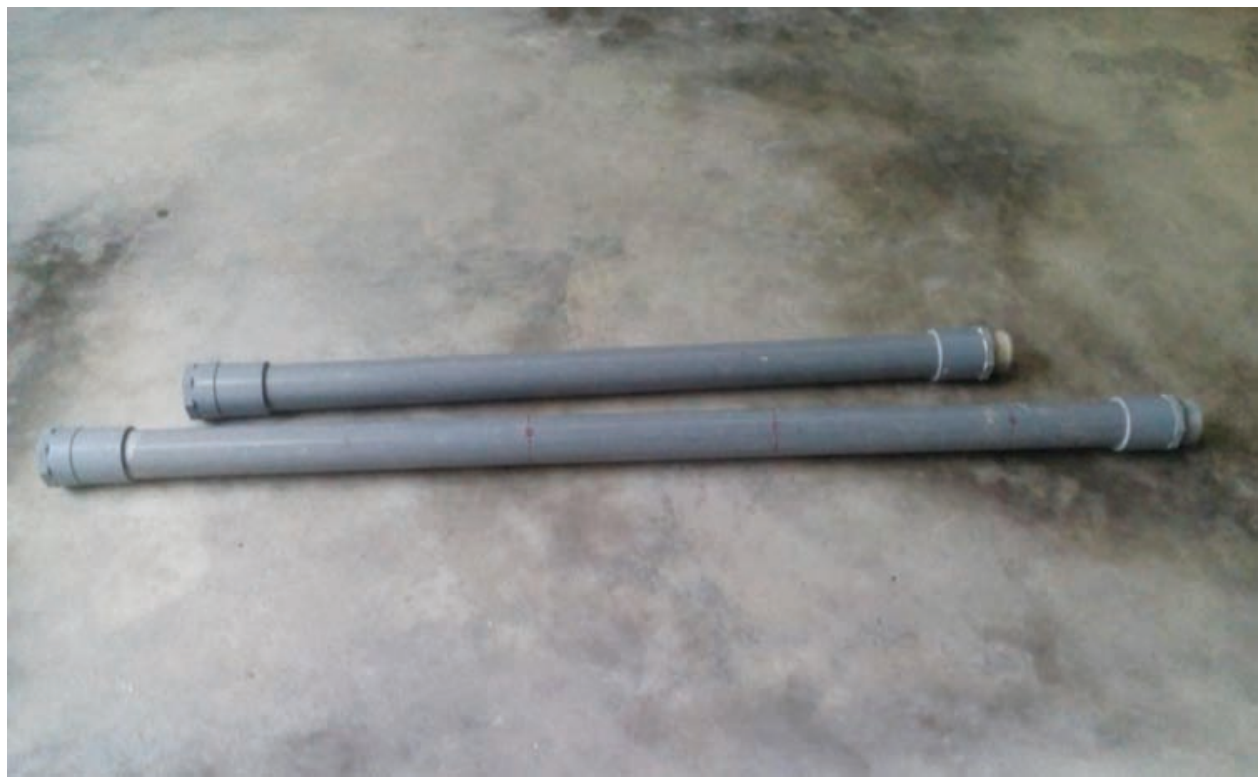

FIGURE 1. Vacuum tube

statistical characteristics of the particle size distribution were presented in the Wentworth $(\phi)$ scale as

$$
\phi=-\log _{2} \mathrm{D} / \mathrm{D}_{0},
$$

where, $\phi$ is the phi scale, $\mathrm{D}$ is the diameter of the particle and $\mathrm{D}_{0}$ is the reference diameter, taken as $1 \mathrm{~mm}$.

\section{RESULTS}

MEAN \& SORTING

Here, the profile of mean for the three studied rivers is first presented in Figure 3a. The mean bed sediment size of Sg. Langat varies from $-1.035 \phi$ to $2.56 \phi$ (i.e. $2.049 \mathrm{~mm}$ to

(a)

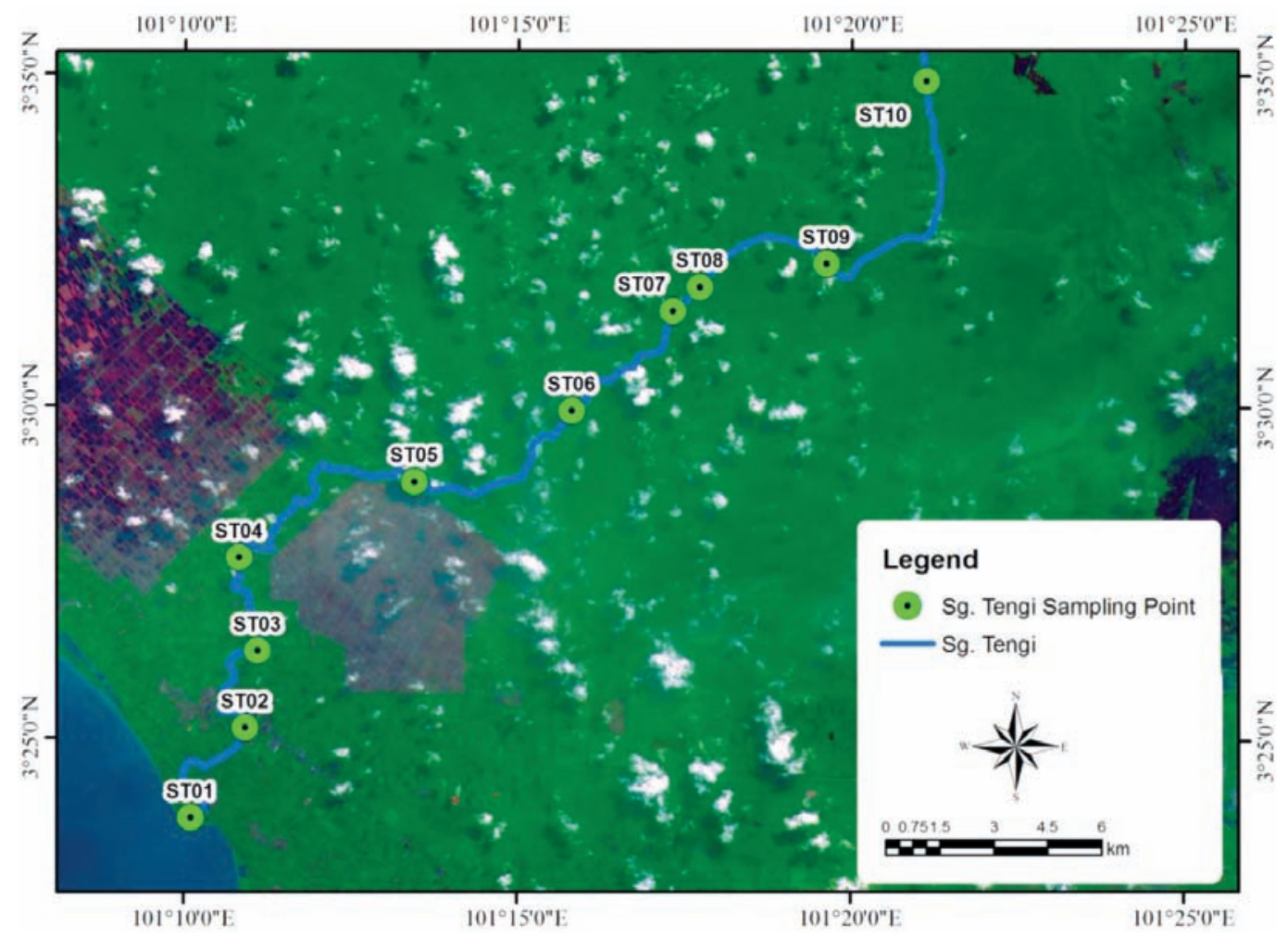


(b)

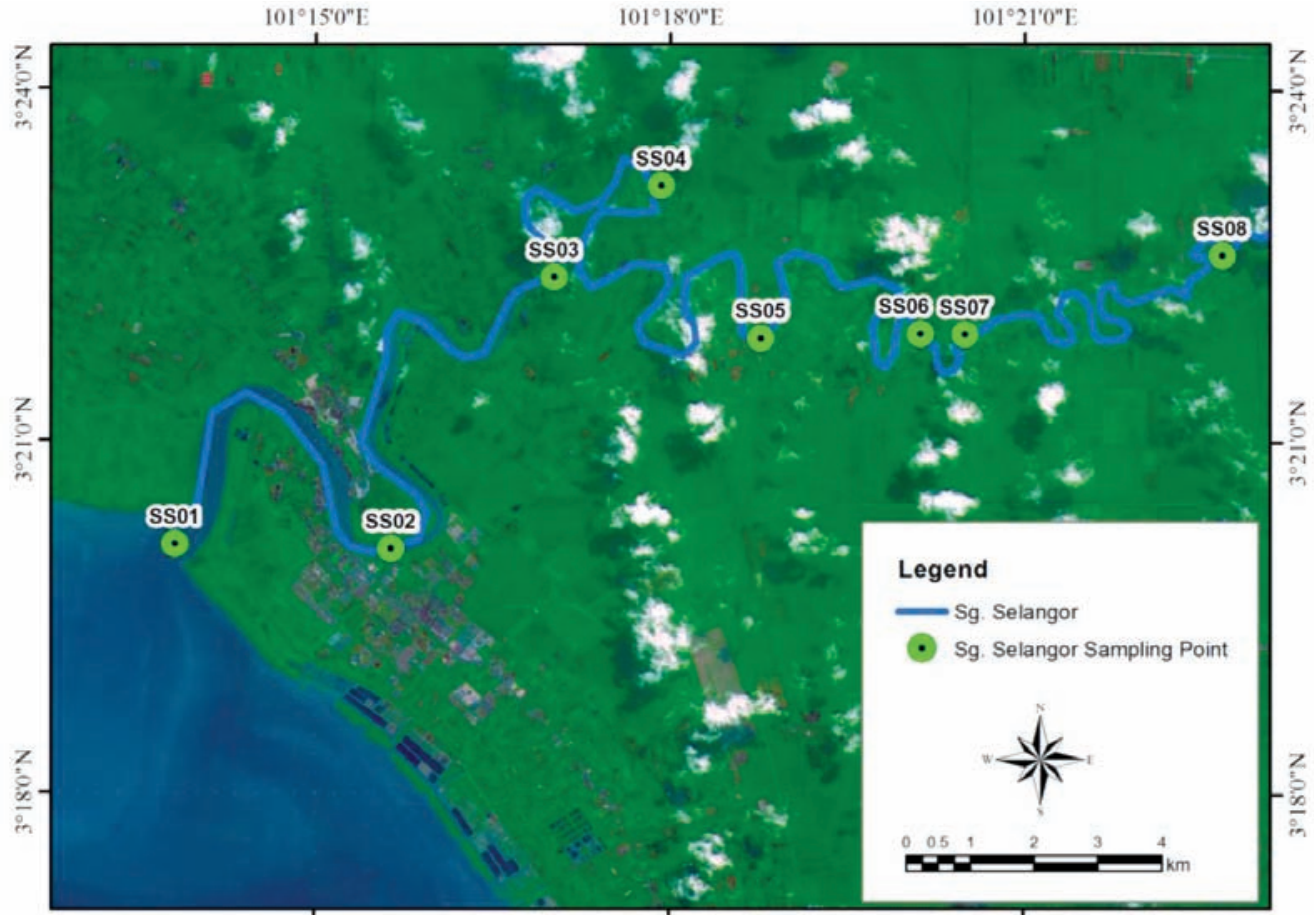

$101^{\circ} 15^{\circ} 0^{\mathrm{E} E}$

$101^{\circ} 18^{\circ} 0^{\prime \prime E}$

$101^{\circ} 21^{\circ} 0^{*} \mathrm{E}$

(c)

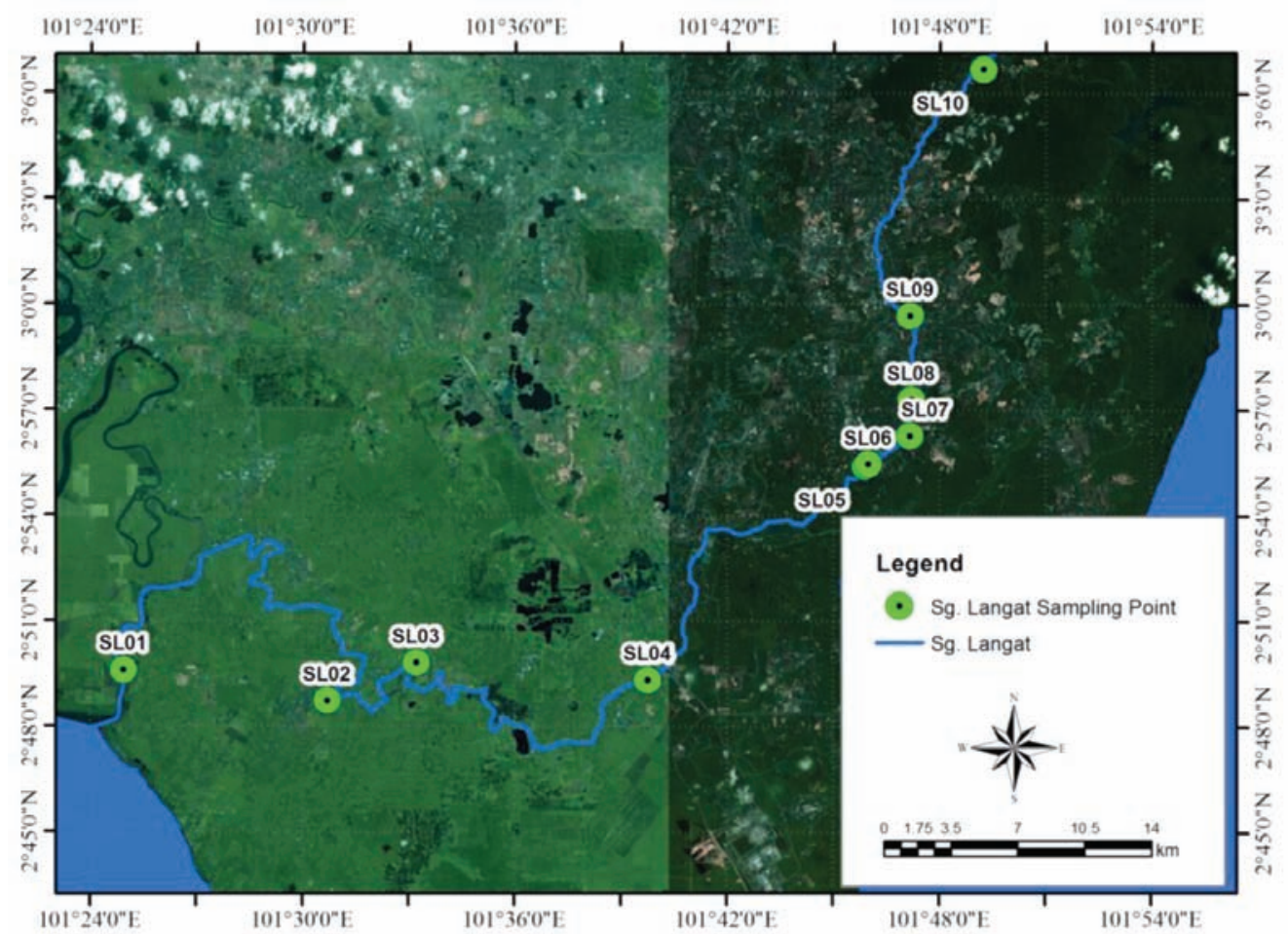

FIGURE 2. Map of sampling area (a) Sg. Tengi (b) Sg. Selangor (c) Sg. Langat. Note that for figures (a)-(c), the point no 01 represents the most downstream, often at the estuary. 
TABLE 2. Statistical formulate used in the calculation of grain size parameters using the logarithmic Folk and Ward (1957) graphical measures

\begin{tabular}{|c|c|c|c|c|c|}
\hline Mean & \multicolumn{2}{|c|}{ Standard deviation } & \multicolumn{2}{|c|}{ Skewness } & Kurtosis \\
\hline$(M)=\underline{\varphi 16+\varphi 50+\varphi 84}$ & \multirow{4}{*}{$\left(\sigma_{1}\right)=\frac{\varphi 84-\varphi 1}{4}$} & $6+\underline{\varphi 95-\varphi 5}$ & \multirow{4}{*}{\multicolumn{2}{|c|}{$\begin{aligned}\left(S k_{1}\right) & =\frac{\varphi 16+\varphi 84-2 \varphi 50}{2(\varphi 84-\varphi 16)} \\
& +\frac{\varphi 5+\varphi 95-2 \varphi 50}{2(\varphi 95-\varphi 5)}\end{aligned}$}} & $\varphi 95-\varphi 5$ \\
\hline 3 & & 6.6 & & & \multirow{2}{*}{$\overline{2.44(\varphi 75-\varphi 25)}$} \\
\hline & & & & & \\
\hline & & & & & \\
\hline \multicolumn{2}{|l|}{ Sorting $\left(\sigma_{1}\right)$} & \multicolumn{2}{|c|}{ Skewness $\left(S k_{1}\right)$} & \multicolumn{2}{|c|}{ Kurtosis $\left(K_{G}\right)$} \\
\hline Very well sorted & $<0.35$ & Very fine skewed & ${ }^{+} 0.3$ to ${ }^{+} 1.0$ & Very platykurtic & $<0.67$ \\
\hline Well sorted & $0.35-0.5$ & Fine skewed & ${ }^{+} 0.1$ to ${ }^{+} 0.3$ & Platykurtic & $0.67-0.9$ \\
\hline Moderately well sorted & $0.7-1.00$ & Symmetrical & ${ }^{+} 0.1$ to -0.1 & Mesokurtic & $0.9-1.11$ \\
\hline Poorly sorted & $1.00-2.00$ & Coarse skewed & -0.1 to -0.3 & Leptokurtic & $1.11-1.5$ \\
\hline Very poorly sorted & $2.00-4.00$ & Very coarse skewed & -0.3 to -1.0 & Very leptokurtuic & $1.5-3.00$ \\
\hline Extremely poorly sorted & $>4.00$ & & & Extremely leptok & $>3.0$ \\
\hline
\end{tabular}

$0.17 \mathrm{~mm}$ ) and data shows the upstream of the river (SL10 as shown in Figure 2c) has the highest value of mean which is equivalent to $-1.035 \phi$ (2.049 mm). Moving downstream the next point SL9 shows a decreasing in mean value, with $-0.009 \phi(1.006 \mathrm{~mm})$ and the pattern continues to decrease until the point SL7, with mean value of $1.947 \phi(0.259 \mathrm{~mm})$. However results shows that there is sudden ascend of mean value at SL6 with $0.253 \phi(0.839 \mathrm{~mm})$. Sudden drop from point SL5 $(0.253 \phi)$ to SL4 $(1.661 \phi)(\approx 0.839 \mathrm{~mm}$ to 0.316 $\mathrm{mm}$ ) were occurred. Point SL3 to SL2 shows increase in mean value from $1.588 \phi(0.333 \mathrm{~mm})$ to $0.685 \phi(0.622 \mathrm{~mm})$ and decrease to point SL1 with mean value $2.560 \phi(0.170 \mathrm{~mm})$. Areas of the upstream and downstream of Sg. Langat show the highest value of mean $2.049 \mathrm{~mm}$ and lowest value of mean $0.170 \mathrm{~mm}$. Sorting of Sungai Langat show similar trend with mean value. As mean size increases, the sorting value increases, few exceptions were shown in points SL8 and SL2 as the mean size increase, the sorting value decrease. According to the mean value in Figure 3, the downstream fining in diameter size of the sediments in Sg. Langat still occurs at every $20 \mathrm{~km}$.

The mean size for sediment mixture collected at Sg. Selangor was found to vary from $0.989 \phi$ to $2.549 \phi(0.504$ $\mathrm{mm}$ to $0.171 \mathrm{~mm})$. As shown in Figure 3b the upstream of Sg. Selangor (ss8) has the mean value of $1.671 \phi(0.314 \mathrm{~mm})$ and further increases to Ss7 with the mean value of $0.989 \phi(0.504$ $\mathrm{mm}$ ). However starting from sampling point of ss6 to ss1, a decreasing trend in the mean value pattern was observed where the mean value for ss6 is $1.565 \phi(0.338 \mathrm{~mm})$, ss 4 (1.627 $\phi ; 0.324 \mathrm{~mm})$, ss3 (1.966 $\phi ; 0.256 \mathrm{~mm})$, ss2 (2.532 $\phi ; 0.173 \mathrm{~mm}), \mathrm{ss} 1$ (2.549 $\phi ; 0.171 \mathrm{~mm})$, respectively. These decreasing pattern of the mean sediment size (from ss7 to Ss1) reflects that fining process of $20 \mathrm{~km}$ downstream (0.989 $\phi$ to $2.549 \phi$ ) of Sg. Selangor.

Further analysis shows that the sediments range from poorly sorted to well sorted. About $75 \%$ of the samples fall in the poorly sorted category as shown in Figure 3b. All the sediments were characterised as sand, coarse, medium and fine sand. The best sorted sediment in all sedimentary environments has mean grain size in the range of fine sand size (Griffiths 1967). The mean value shows that the downstream fining possibly occur within $15 \mathrm{~km}$ downstream starting from point Ss7 to Ss1.

Samples obtained from Sg. Tengi showed a varying range of mean values from $1.313 \phi$ to $3.302 \phi(0.402 \mathrm{~mm}$ to 1.101 $\mathrm{mm}$ ) in the downstream direction. Starting from the upstream point, ST10, the mean value is $2.569 \phi(0.168 \mathrm{~mm})$. The value decreases to the next point ST9 with the mean value of 3.302 $\phi(0.101 \mathrm{~mm})$. Further downstream ST7 shows an increase of the mean value to $2.564 \phi(0.169 \mathrm{~mm})$. The mean value then descends back at ST6 with the mean size value $3.356 \phi(0.098$ $\mathrm{mm})$. ST5 shows a drastic increase with the mean value 1.716 $\phi(0.304 \mathrm{~mm})$ and point ST4 and ST3 show a slightly increase with the mean value of $1.607 \phi(0.328 \mathrm{~mm})$ and $1.313 \phi$ (0.402 mm) respectively. Meanwhile point ST2 and ST1 shows slightly decreases with the mean value $1.606 \phi(0.328 \mathrm{~mm})$ for ST2 and $1.684 \phi(0.311 \mathrm{~mm})$ for ST11. The sorting shows increasing trend shows as the mean value increases at the first $10 \mathrm{~km}$ in downstream direction. However, the variation trend of sorting values decreases as the mean sediment size increases after the $10 \mathrm{~km}$ downstream direction. Therefore, no downstream fining trend was observed for Sg. Tengi.

Overall findings show that similar pattern of downstream fining was observed in the mean and sorting of Sg. Langat (within $20 \mathrm{~km}$ downstream), Sg. Selangor (within $15 \mathrm{~km}$ downstream) and Sg. Tengi (upstream fining within $18 \mathrm{~km}$ upstream. Figure 3 shows Sg. Langat is the longest river with highest overall mean sediment size recorded among the three rivers. Meanwhile the sorting recorded does not show any trend in to differentiate the rivers.

SKEWNESS (SK) \& KURTOSIS (K)

Value of skewness dictates the distribution of the bed sediment profile about mean. Skewness in the sediment bed at Sg. Langat (Figure $4 a$ ) has range between -0.571 to 
(a)

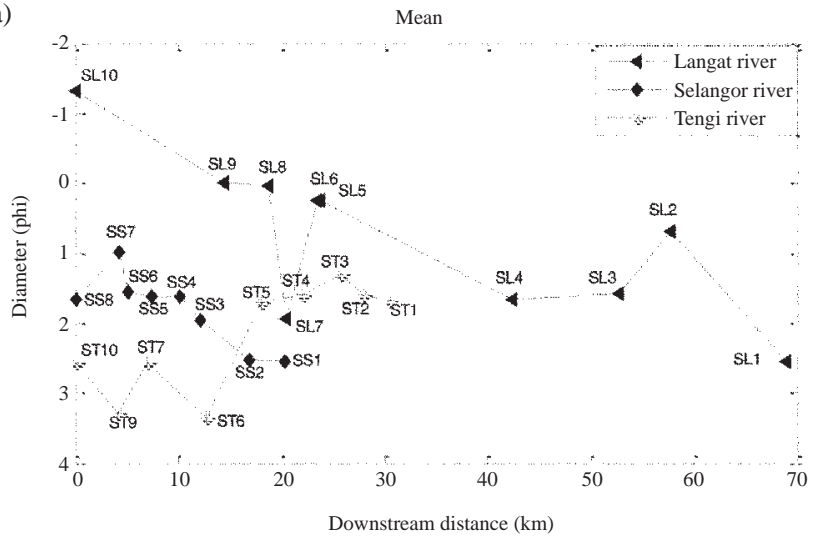

(b)

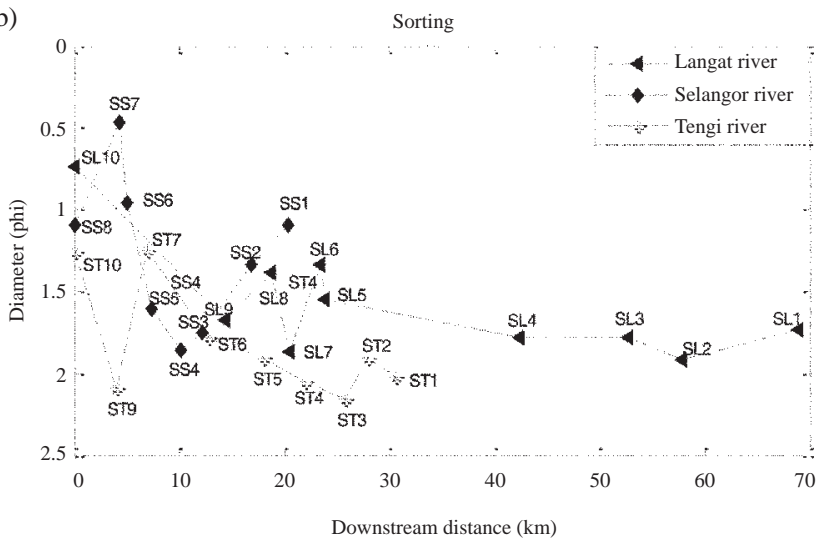

FIGURE 3. Downstream changes of mean and sorting in Sg. Langat (४), Sg. Selangor (») and Sg. Tengi (*)

$0.483 \phi(1.083 \mathrm{~mm}$ to $0.715 \mathrm{~mm})$. The sediment follows the downstream directions, whereby the symmetry of the samples varies from very fine skewed to very coarse skewed. Skewness value of SL10 (the upstream of Sg. Langat) shows the value $0.483 \phi(0.715 \mathrm{~mm})$, followed by SL9 $(0.313 \phi$; $0.805 \mathrm{~mm}$ ) presenting an increase of very fine skewed. Next SL7 shows increasing skewness by a decrease in skewness for the next point SL8 $(0.359 \phi ; 0.780 \mathrm{~mm})$ within the same range of very fine skewed. Next SL7 shows increasing skewness value $(-0.220 \phi ; 1.164 \mathrm{~mm})$, then decreases to the next point, SL6 $(-0.115 \phi ; 1.083 \mathrm{~mm})$ and increases at sampling point of SL5 $(-0.186 \phi ; 1.138 \mathrm{~mm})$ which exhibit the sediments were in the range of coarse skewed range. Next SL4 and SL3 show decreasing in the downstream direction with the skewness value $0.132 \phi(0.913 \mathrm{~mm})$ and $0.169 \phi(0.889$ $\mathrm{mm}$ ) respectively, both were in the fine skewed range. The skewness value increasing at the point SL2 and SL1 with the value of sediment skewness were $-0.014 \phi(1.010 \mathrm{~mm})$ and $-0.571 \phi(1.485 \mathrm{~mm})$ respectively. Both point lies under the range of very coarse skewed particles. About $30 \%$ of the samples in Sg. Langat fall in both very fine skewed and coarse skewed respectively, whereas the rest were $20 \%$ fall in the fine skewed and $10 \%$ falls in symmetrical and very coarsely skewed. The kurtosis of Sg. Langat shows horizontal trend follow the downstream variation. Overall of the samples, $70 \%$ were recorded as platykurtic, $20 \%$ of samples shows deficiently peaked (leptokutic) and $10 \%$ of the sediments were mesokurtic.

Samples collected from Sg. Selangor has skewness varies from -0.165 to $0.643 \phi$ (1.121 to $0.64 \mathrm{~mm}$ ) shows that the samples skewed from very fine skewed to coarse skewed as can be seen in Figure 4a. The upstream of Sg. Selangor ss8, shows the skewness value $0.009 \phi(0.994 \mathrm{~mm})$ lies under the range of symmetrical skewness. The next point Ss7 decrease in skewness value with $0.643 \phi(0.640 \mathrm{~mm})$ shows the sediment range in fine skewed. Then increasing trends of skewness were observed for sampling point of ss6 and ss5 with the magnitude of $-0.165 \phi(1.121 \mathrm{~mm})$ and $(0.027$ $\phi ; 0.981 \mathrm{~mm}$ ) respectively which both points represent the skewness of coarse skewed and symmetrical. Skewness for point ss4 and ss3 decreases in downstream direction with magnitude of $0.164 \phi(0.893 \mathrm{~mm})$ for Ss4 and $0.265 \phi$ $(0.832 \mathrm{~mm})$ for ss3 showing fine skewed range. Point ss2 shows increase in skewness value $-0.083 \phi(1.059 \mathrm{~mm})$ and decreases to $-0.014 \phi(1.010 \mathrm{~mm})$ at point Ss1. Both samples at Ss2 and ss1 show the skewness range in symmetrical.

Figure 4a shows Sg. Tengi skewness range from -0.089 to $0.466 \phi$ (1.064 to $0.724 \mathrm{~mm})$. The range falls within very fine skewed to symmetrical. Sg. Tengi upstream point (ST10) shows the skewness value $-0.0869 \phi(1.064 \mathrm{~mm})$ decrease to the next point ST9 $(0.451 \phi ; 0.732 \mathrm{~mm})$ which represent the symmetrical very fine skewed respectively. Moving downstream ST7 having a skewness value of $0.140 \phi(0.908$ $\mathrm{mm}$ ) then sT6 with $0.005 \phi ; 0.996 \mathrm{~mm}$. Both shows decreasing in skewness value follows the downtsream direction and lies under fine skewed and symmetrical, respectively. Magnitude of skewness for point ST5 is $-0.149 \phi(1.109 \mathrm{~mm})$ displays some increase with the skewness range of fine skewed. Further calculation exhibit a decrease in skewness at point ST4 and ST3 from $0.247 \phi(0.842 \mathrm{~mm})$ to $0.466 \phi(0.724$ $\mathrm{mm})$. ST4 is fine skewed whereas ST3 in the range of very fine skewed. Point ST2 shows increasing in skewness value compared to the previous point with $0.199 \phi(0.871 \mathrm{~mm})$ and decreased at point ST1 with the skewness values of $0.209 \phi$ $(0.865 \mathrm{~mm})$. Both sediments showed the value under the fine skewed. Overall analysis present $60 \%$ of the sediment is in the fine skewed and the other $20 \%$ in the very fine skewed and $20 \%$ is in the symmetrical sediment size group.

The value of kurtosis in Figure 3b for the upstream Sg. Selangor point at Ss8 displays a leptokurtic range. Then point ss7 shows an increase in kurtosis value of $0.496 \phi(0.709 \mathrm{~mm})$ that is in very platykurtic sediment group and going further to point Ss6 with the kurtosis value of $1.208 \phi(0.433 \mathrm{~mm})$, categorised as leptokurtic. Point ss5 has an increase kurtosis value of $0.804 \phi(0.573 \mathrm{~mm})$ and further decreased at point ss4 to $1.108 \phi(0.464 \mathrm{~mm})$. Therefore, ss5 has platykurtic distribution and sample at Ss4 is mesokurtic. The next point ss3 displayed a descending in kurtosis value of $0.872 \phi(0.546$ $\mathrm{mm}$ ) which can be categoried as platykurtic. ss2 shows an abrupt drop in kurtosis value of $10.75 \phi$ which is under the extremely leptokurtic. Point Ss1 shows increasing kurtosis value compared to previous point with $1.498 \phi(0.354 \mathrm{~mm})$ 
that is leptokurtic kurtosis. Most of the samples for Sg. Selangor (about 50\%) were identified as deficiently peaked, that is either extremely leptokurtic or leptokurtic.

Meanwhile for Sg. Tengi, the values of kurtosis were in the range from $0.849 \phi$ to $8.301 \phi(0.003$ to $0.555 \mathrm{~mm})$, displaying a platykurtic to extremely leptokurtic kurtosis pattern. The upstream point ST10 showed the kurtosis value of $8.301 \phi(0.003 \mathrm{~mm})$ which is extremely leptokurtic. The next points are ST9 and ST7, presenting an increase in kurtosis value of $0.942 \phi(0.732 \mathrm{~mm})$ and $1 \phi(0.500 \mathrm{~mm})$

(a)

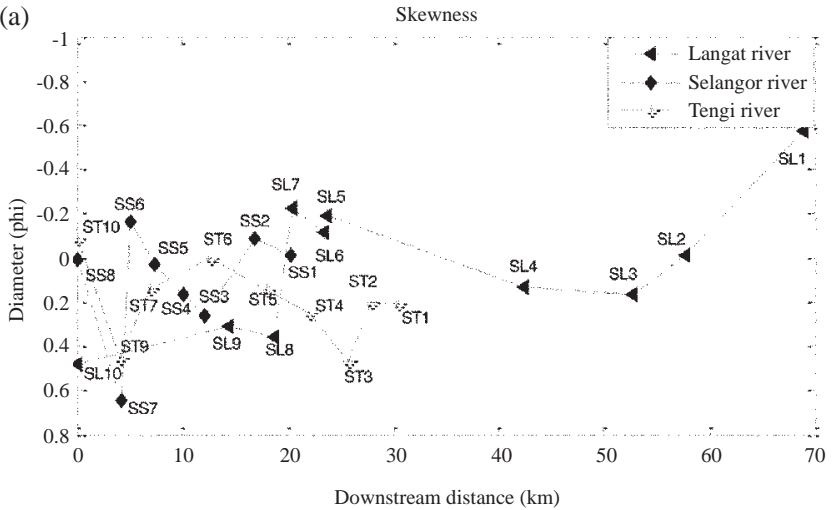

with both are mesokurtic. Then, ST6 has a kurtosis value of $2.166 \phi(0.223 \mathrm{~mm})$ which is very leptokurtic. The last five points including ST5, ST4, ST3, ST2 and ST1 following the dowsntream direction showed a horizontal trend with the value recorded within the range $1.177 \phi$ to $0.849 \phi(0.442$ $\mathrm{mm}$ to $0.555 \mathrm{~mm}$ ). All point lies under platykurtic, mesokurtic and leptokurtic kurtosis. In summary for Sg. Tengi, $60 \%$ of the samples fall under mesokurtic and another $10 \%$ were fall in platykurtic, extremely leptokurtic, very leptokurtic and leptokurtic. (b)

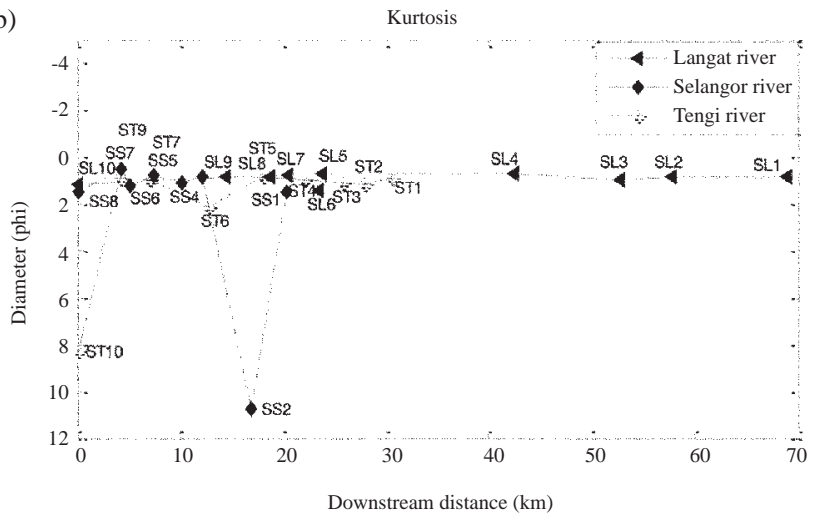

FIGURE 4. Downstream change of skewness and kurtosis in Sg. Langat (४), Sg. Selangor ( ) and Sg. Tengi (*)

BIVARIATE SCATTER GRAPHS OF GRAIN SIZE PARAMTERS

Figure 5 shows the bivariate plot of mean versus sorting (Figure 5a), sorting versus skewness (Figure 5b) and skewness versus kurtosis (Figure 5c). Bivariant plot used to single out the different depositional setting follows the expectation of statistical parameters accuracy which reflects the fluvial mechanisms of sediment transportation and deposition (Sutherland and Lee 1994). Figure 5a below shows relationship of mean grain size and sorting of the three rivers. Tucker (1990) stated that mean grain size and sorting can show some covariance and both are hydraulically controlled (Griffiths 1967).

The best sorted sediments in any sedimentary environments will have the mean grain size within the fine sand size range. Figure 5a, indicates a positive the trend increase of sorting values with the increasing magnitude of mean. More than half of the sediments were poorly sorted with the mean size clustered in the medium sand and very fine sand range. Few samples collected in Sg. Tengi deviate from others and were categorized as very poorly sorted with medium sand range.

Figure $5 \mathrm{~b}$ shows the relationship of sorting and skewness and most of the sediments in were poorly sorted and fall on fine skewed and symmetrical range. More than half of the sediments were considered as positively skewed. It simply shows that sediment were grouped in sorting range $0.5 \phi>$ $\sigma_{1}>0.5 \phi$ and $-0.6 \phi>S k>0.6 \phi$ (Folk and Ward 1957). Few sediment samples in $\mathrm{Sg}$. Tengi have very poorly sorted range with the fine and very fine skewness.
Figure 5c shows plotting of skewness against kurtosis which is an impressive tool in intrpreting the sediment genesis with the evaluation the degree of normality of the distribution size (Folk 1966). Majority of the sediments lie within positively skewed and accumulates in mesokurtic and leptokurtic group. This shows that the influence of medium grain size group and the collateral of few coarse and fine grain sizes give the positively skewed. This suggests that the present of more fine sand in the sediment will give the positively skewed results, and the coarser sand give the negatively skewed. However, the fluvial sediment of this three river shows there are from fine sand and less gravel follow the downstream.

\section{CONCLUSIONS}

From fieldwork data and analysis show the inconsistent downstream variation in the fluvial sediment mixture of Sg. Selangor, Sg. Langat and Sg. Tengi. It can be seen that within the given data, Sg. Selangor and Sg. Langat have the profiles of the downstream fining where the mean size of particle is decreasing towards the estuary. However different trend of fining could be observed for Sg. Tengi probably due to the least developed area along the river bank compare to Sg. Selangor and Sg. Langat area. As a conclusion, the bed sediment for Sg. Selangor, Sg. Langat and Sg. Tengi mostly consist of medium sand at the upstream and is categorized as fine sand as reaching towards the estuary. 
(a)
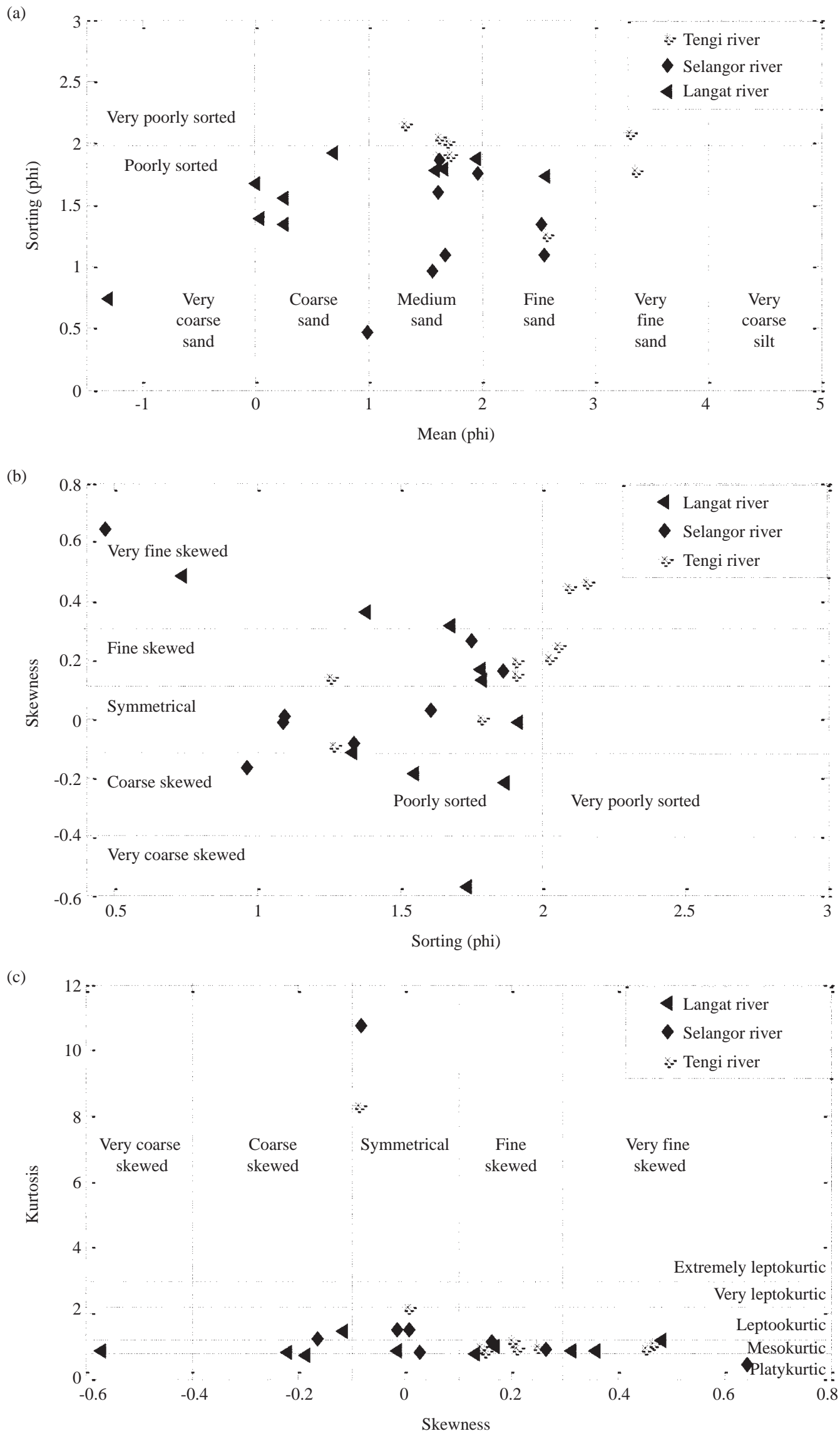

FIGURE 5. Sector plot showing the bivariant relationship between (a) The grain size and sorting, (b) Sorting and Skewness (c) Skewness and Kurtosis of the Sg. Langat (४), Sg. Selangor ( $\bullet$ and Sg. Tengi (*). 
ACKNOWLEDGEMENTS

This work was supported by the Research Fund provided by ERGS/1/2013/TK03/UKM/02/7 and 06-01-02-SF1077. The authors are extremely grateful for the financial support by Ministry of Education and Ministry of Science, Technology and Innovation.

\section{REFERENCES}

Amireh B. S. 2015. Grain size analysis of the Lower Cambrian-Lower Cretaceous clastic sequence of Jordan: Sedimentological and paleo-hydrodynamical. Journal of Asian Earth Sciences 97: 67-88.

Gomez B., Rosser B. J., Peacock D. H., Hicks D. M. \& Palmer J. A. 2001. Downstream fining in a rapidly aggrading gravel bed river. Water Resources Research. 37: 1813-1823.

Gasparini, N. M., Tucker, G. E. \& Bras, R.L. 1999. Downstream fining through selective particle sorting in an equilibrium drainage network. 1999. Geology 27: 1079-1082.

Griffiths, J.C. 1967. Scientific Methods in the Analysis of Sediments. New York. McGraw-Hill

Siti Aminah Bassa Nawang Mohd Noor Shafique Rahman Wan Hanna Melini Wan Mohtar

Department of Civil Engineering \& Structure

Faculty of Engineering \& Built Environment

Unversiti Kebangsaan Malaysia

43600 UKM Bangi, Malaysia

Phone: + 603 - 89216229

Email address: aminahbassa@gmail.com; mohdnoorshafiquerahman@gmail.com; hanna@ukm.edu. my
Ferguson, R., Hoey, T., Wathen, S. \& Werrity, A. 1996. Field evidence for rapid downstream fining of river gravels through selective transport. Geology 24: 179-182.

Folk, R. L. 1966. A review of the grain size parameters. Sedimentology: 73-93.

Frings, R. M. 2008. Downstream fining in large sand-bed rivers. Earth Sciences Reviews 87: 39-60.

Rice, S. 1999. The nature and controls on downstream fining with sedimentary links. J. Sediment. Res. 69: 32-39.

Dongwei, G., Jiaqiang, L., F. anjiang Z., Runge, M., Guijin, M., Faxiang, Y. \& Juntao, Z. 2010. Ordination as a tool to characterize soil particle size distribution, applied to an elevation gradient at the north slope of the Middle Kunlun Mountains. Geoderma. 158: 352-358.

Tucker, M. 1990. Techniques in Sedimentology. Blackwell Scientific Publications. 63-86.

Xia Liu, Guangcan Zhang, Gary C. Heathman, Yaqin Wang \& Chi-hua Huang. 2009. Fractal features of soil particlesize distribution as affected by plant communities in the forested region of Mountain Yimeng, China. Geoderma. 154: 123-130. 
